\title{
The Use of Terminology in Reporting Islam: A Comparative Analysis
}

\author{
Isyaku Hassan ${ }^{1}$, Mohd Nazri Latiff Azmi ${ }^{1} \&$ Usman Ibrahim Abubakar ${ }^{2}$ \\ ${ }^{1}$ Faculty of Languages and Communication, Sultan Zainal Abidin University, Terengganu, Malaysia \\ ${ }^{2}$ Department of Mass Communication, Bayero University Kano, Nigeria \\ Correspondence: Isyaku Hassan, Faculty of Languages and Communication, Sultan Zainal Abidin University, \\ 21300 Kuala Terengganu, Malaysia. E-mail: isyaku87@gmail.com
}

Received: June 12, 2017 Accepted: July 10, 2017 Online Published: October 11, 2017

doi:10.5539/ijel.v7n6p236 URL: http://doi.org/10.5539/ijel.v7n6p236

\begin{abstract}
The use of terminology in reporting Islam has been one of the major concerns of many scholars and religious experts in recent years. Specifically, the media's selection of words to describe Islam attracts attention of many righteous people. Words such as extremist, terrorist, militant, insurgent are mostly used to describe Muslims. This indicates the need to explore how the media particularly newspapers use terminology in reporting Islam, since people rely on the media for news and information. The present study focuses on content analysis of terminology used to describe Islam in selected Nigerian and Malaysian English newspapers. Two different divisions of sampling procedure were employed; sampling for the newspapers and sampling for related articles in the newspapers. The study used purposive sampling to gather data. Punch and Vanguard were chosen from Nigeria while The Star and New Straits Times were chosen from Malaysia based on their popularity and readership. Meanwhile, an internet-based search for news articles on Islam was performed. The aim was to locate the news articles relating to Islam in the selected newspapers. Articles between November 2015 and September 2016 were selected. Any article that focuses upon reporting Islam or Muslims fulfills the inclusion criteria. The content of each article was examined and read for relevance. The newspapers produced 599 different Islam-related articles within this period. The study found that 260 different Islam-related terms appeared in the selected newspapers. But Malaysian newspapers used more (200) of these terms than Nigerian newspapers, which used only 60. However, the most frequently used Islam-related term in the selected newspapers is "Islamist militants" which appeared 60 times, followed by "radical Islam" and "Islamist attacks", which came second and third respectively. It was found that these words were used in negative context. It is therefore recommended that journalists should make an effort to understand clear connotation of the terminology they use, and use them properly. Newspapers should mind the use of terms in or order to avoid creating negative perception toward Islam.
\end{abstract}

Keywords: Islam, English newspapers, Islam-related terminology

\section{Introduction}

The world, particularly the Middle East and some other countries, is currently in a quandary of terrorism and events so sanguinary that draw attention of many righteous people. This is because the masses could be left susceptible to the messages disseminated via the media against Islam. Since the attacks of the World Trade Centre on September 11, 2001 in the U.S, much media attention has focused on Islam as a disruption in the global order. It should be noted that every newspaper has a particular way of describing the perpetrators, and particular newspaper may be using the terms more than others, although other similar terms can be used within the same article. The use of any of these terms may have the desired effect of turning the reader's attention toward a particular idea or phenomenon. It would not be an overstatement to say that in many people's minds the use of the terms would simply have reinforced negative stereotypes regardless of the context of the articles. Frequent use of the terms definitely reinforces previously held prejudices and fears about Islam and Muslims. Such terms are used in authoritative tones by some journalists who have no idea of their accurate connotation. In fact, several words and phrases that are offensive and pejorative to Muslims have become part of media language (Ahmad, 2006; Thussu, 2011).

Pertaining to the relationship between media and Islam, studies (Haque, 2012; Allen, 2001; Said, 2000) pointed out that Islam is often associated with extremism, terrorism, and fundamentalism through selection of words to 
describe Islam. The power of words can never be overemphasized, and therefore how they are being used particularly in the written communication matters greatly. It can be argued that print media continues to play a vital role in the way people perceive religion, and journalists bear a great responsibility in the use of misleading terms such as extremist, fundamentalist, fanatic and terrorist in reporting religion (Allen, 2001). This indicates the need to explore how the media particularly newspapers use terminology in reporting Islam, since people rely on the media for news and information. In sum, the media, particularly newspapers report Islam using terms such as "Muslim terrorist" or "Muslim extremist" which can be associated with certain thoughts that are predominant in the audience's mind set. Nouns or adjectives like "terrorist", used in conjunction with Islam or Muslims might create certain connotation (Thompson, 2013).

Much communication literature proposes that news does not merely disseminate facts on a topic, but also serves as a source through which ideology is conveyed. Researchers pointed out that this can be identified in newspaper articles through choice of words to depict a party involved in a particular event; Islam in the case of this study (Allen, 2001; Abbas, 2001; Moore et al., 2008; Thussu, 2011; Schneider, 2011; Ridouani, 2011; Haque, 2012; Baker et al., 2013; Allen, 2014; Wariboko, 2015). Hence the present study aims to comparatively determine the most frequently used terms in reporting Islam, particularly in Nigerian and Malaysian newspapers; and examine the context in which the terms are used.

\subsection{The Use of Terminology in Reporting Islam}

News media content is dominated by terms such as Islamist terrorists, Islamist extremists, Islamist militants, Islamist insurgents, and Islamist gunmen who may or may not be Muslims. Rane et al. (2014) clarified that the media's preoccupation with the extremes in the Muslim world prevents any awareness of typical Muslim life and offers legitimacy to terrorists, who may or may not be Muslims, as representatives of Islam. Accordingly, those who rely on the mass media for understanding Islam are likely to gain a view of the complete image, or even the main image portrayed in the media. The statements and actions of a minority of Muslims are considered newsworthy and dominate the popular generosity of Islam. Moore et al. (2008) found that the language used in reporting Islam reflects the negative context in which they tend to appear. Muslims are often identified simply as Muslims rather than individuals or groups with distinct identities; they were not identified in terms of their jobs or professions. Akbarzadeh \& Smith (2005) pointed out that international events that implicate Muslims and Islam do not necessarily discuss "Muslims" and "Islam" in their reporting, but rather use particular terminology such as "Islamic terrorism", "jihad", and "Muslim fanatics" to describe and contextualize the type of violence being carried out.

The manner in which language is utilized in media discourse on Islam needs serious attention. Even prior to 9/11, Muslims were already disappointed with the media's persistent usage of sensationalist terminology such as "Islamic terrorists" and "Muslim fundamentalists". The observed "double standards" in relation to western foreign policy intended for Muslims were perceived to be facilitated through language. Meanings of terms such as "fundamentalism" and "terrorism" were hardly questioned in the news media. Nevertheless, terms such as "democracy" and "freedom fighters" hold highly political and subjective meanings, but are infrequently used in circumstances that support interests of Muslims (Ahmad, 2006).

Other terms such as "moderate Islam" or "moderate Muslims" have been extensively criticized in the literature. Jacobsen et al. (2012) argued that when moderate Muslims appeared in the media, it is likely to be in articles on extremism, where a difference is indirectly made between the liberal, moderate, modern Muslims and the extremist, Islamist, and traditional Muslims. In this case, the moderate Muslims become the good people that are on "our" side in the fight against extremism, which means the rest of the Muslims are instinctively considered as terrorists. In a similar vein, Baker et al. (2013) asserted that terms like "moderate Muslim" could imply that many Muslims are not moderate. Schneider (2011) went on stressing that if the typical Muslim believes in a moderate Islam, then what is the "usual Islam"? This predication strategy assigns the "usual Islam" the feature of being non-moderate. Here the "non-moderate" is equivalent to extreme, which leads to a cognitive model in which the concepts of Islam and Islamism or militancy are intensely interrelated, and Islam as such is regarded as inclined to extremism. Abbas (2015) noted that "extremism" is a result of marginalized voices unable to find expression in the social world. It applies as much to Muslims as it does to other disaffected groups in societies.

In addition to the aforecited terms, concept of jihad is generally misunderstood (Nayan, 2017). In this regard, Kukah (2011) held that if he had not seen how his faithful Muslim friends lived and used pen for jihad, he would have believed that jihad is all about violence. In the words of Wariboko (2015), terrorism cannot be considered synonymous to Islamic jihad. The author noted that whenever jihad is mentioned, most non-Muslims assume it is synonymous with violence against non-Muslims. But Islamic jihad does not signify violence as many 
non-Muslims erroneously believe. The concept of Jihad, which has undergone a series of deformations, has been stripped from its religious and spiritual meaning. This means that the media shortened Jihad to a mere act of terrorism, which has completely changed its connotation. The word Jihad can refer to "refraining from wrongdoing" or "struggling to up-bring family", but it only refers to defense and never an attack when used as "holy war" (Ridouani, 2011). In this regard, the juxtaposition between the Islamic values and violence is a distortion of facts that is mainly initiated by the society's ignorance about Islam. Muslim words like jihad have been completely seized into general journalistic vocabulary and have been capitalized with new negative connotation. Unfortunately, its new journalistic connotation signifies violence (Abbas, 2001).

In addition, an Islamist is a Muslim who wants predominantly Muslim state to be managed according to Islamic law. But the word "Islamist" is mostly used to refer to an armed Muslim, militant, radical, and extremist. In Islam, there is no separation between the state and religion, but political Islam is described as undesirable. The word "Islamism" is used synonymously with militant Islam, radical Islam, political Islam (Ali et al., 2008). The vagueness of terms used to describe Muslims has a very framing consequence. The lack of clear definitions results in the tendency of identifying Muslims with Islamists and Islam with Islamism. In fact, both are perceived to be closely related, which accordingly results in marginalization of Muslims.

Words such as "Islamists", "extremist" and "radical" are regularly used in headlines across all forms of the media. They create certain impression and a tendency to view all Islamic movements as originating from the same root and as being equally violent. These words affirm the fear that a perceived "Islamic threat" prevails in the media. In most cases, the media use the words like "Islamists" to refer to insurgents. Maybe "Islamist" is another name used for a terrorist, but the word "terrorism" has no the word "Islamic" in its definition. Wariboko (2015) posited that non-Muslims must understand that just as the followers of other religions are obviously misguided and cannot be considered as representative their religions, terrorists should also not be considered as Muslims, hence the adjective "Islamic" should not be used to qualify terrorists even though they claim to be Muslims. Generally, religion should not be used to identify those who involve in violent acts.

Also the dominant topic existing throughout narratives produced by the print media is related to the concept of "Islamic fundamentalism" (Abbas, 2001). The term "Muslim fundamentalism" is now used defectively as a label to designate every movement with a religious Islamic signature. The term is vague, but it is extensively used in the media (Shadid \& Van Koningsveld, 2002). According to Schneider (2011), the term "Muslim fundamentalist" suggests a much stronger relation between Muslims and "Islamist extremists" than the word "Islamist" does. In addition, news reporters mostly distort the proper meaning of the term "fundamentalism". Its religious connotation refers to adherence to religious doctrine as it is. If the term means a typical and accepted way of worshiping God, then why should it be otherwise in the media? It seems the term "fundamentalism" is exclusively related and even restricted to Islam and Muslims. When the media apply "fundamentalism" to Islam and Muslims, it is mostly stripped from its literal connotation and granted an extremism and terrorism connotation (Ridouani, 2011).

Ali et al. (2009) also pointed out that a variety of phrases have been applied and associated with Islam. These phrases include "Islamic militant from Pakistan", "Pakistan backed Muslim rebels", "Islamic terrorist training camp", and "Islamic fundamentalist theme". Muslims are identified as a social grouping based on their faith and religious practices. Emphasis is usually placed on their Muslim identity rather than nationality, race and ethnicity. In this regard, Ali, et al. (2008) raised an important question - is it necessary to identify those who commit violent acts with their religion? - expatiating that there are various terrorists of all types all over the world. But Muslims who involve in violent acts are mostly identified with their religion, discounting other social or political factors that could be in play (Nanabawa, 2013).

\subsection{Theoretical Approach}

This study is based on McCombs \& Saw's (1972) Agenda Setting theory which focuses on media presentation of issues according to their agenda (Potter, 2012). The basic assumption of this theory is that the media create a particular image of reality whether consciously or unconsciously, and then confront the audience on a daily basis with issues that are important according to the media. As a result of omission of certain issues and emphasis on others, a particular way for the audience to think about reality is established (Fourie, 2001). Nonetheless, McQuail (1987) argued that despite various studies conducted on Agenda Setting theory, there is still insufficient evidence to indicate causal relationship between the public's ordering of priorities and the order of prominence placed on issues in the news media. Understanding the wider world has been attributed to effective use of information disseminated through the media, especially in the digital age of communication. But the direction, nature and extent of this influence remain a source of disagreement (Okwuchukwu, 2014). 
The theory enables construction of societal beliefs and dissemination of values and devalues of a particular topic. People's attention is shifted away from immediate effects on attitudes and opinions to long term effects on cognitions. Newspapers offer cues about the salience of issues in the daily news, such as in lead story on page one, other front page display, and large headlines. By repeating these cues day after day, the newspapers effectively communicate the importance of each issue. In this case, how much importance attached to an issue depends on the emphasis placed on it in the news (Okwuchukwu, 2014). According to Folarin (1998), there are four elements associated with agenda-setting - the extent or frequency of reporting, the degree of conflict generated by the reports, the level of prominence attributed to the issue, and the collective media-specific effect over time. The ability of media to raise the importance of an issue in the public's mind depends on these elements. Based on Agenda Setting theory, it can be argued that using these terms on a daily basis may influence people's perception about Islam. Wariboko (2015) also opined that a clear demarcation should be made between Muslims and terrorists who commit violent acts in the name of religion.

\section{Method}

This study used content analysis to compare the use of terminology in selected Nigerian and Malaysian newspapers. Gardner et al (2008) noted that comparative analysis is proven to be the best way not only to help explain certain phenomena occurring in different countries, but also to clarify issues relating to one country by comparing them to similar issues in other countries. Dart \& Allen (2000) also noted that one way to analyze charges of unfairness and preconceived notion in news reporting is to choose a particular issue and compare how various news organizations have handled the subject. Newspapers are the focus of this study as newspaper readers have a reasonable control level over their news consumption since they can attend to news at any time, as posited by Soroka (2002). The researcher chooses content analysis as it centers on media message characteristics, and allows researchers to understand social reality in a subjective but scientific manner. Content analysis enables researchers to measure the content of texts by examining the statistic occurrence of defined units such as arguments or terms (Neuendorf, 2002; Langer, 1997). Cissel (2012) also noted that content analysis allows for the comparison of possible agenda setters' bias of events.

\subsection{Sampling Procedures}

Two different divisions of sampling procedure were used; sampling for the newspapers and sampling for related articles in the newspapers. The study employed purposive sampling for the newspapers and articles included in the analysis. Purposive sampling refers to a form of non-probability sampling in which decisions concerning the elements to be included in the sample are taken by the researcher (Palys, 2008). Two national newspapers with highest readership were chosen from form each country. Punch and Vanguard were chosen from Nigeria while The Star and New Straits Times were chosen from Malaysia. Nigerian and Malaysian newspapers were selected simply on the basis of both sharing similarities from religious and media perspectives in many ways. Both newspapers can be historically traced to the colonial era under British colonial masters, and the countries are to a large extent English speaking. They are Muslim majority countries, having had earlier contact with Islam. It would be interesting to see how newspapers in Muslim majority countries use terminology in reporting Islam (Ridgeon 2013; Saidu 2014).

Regarding news articles, sample was collected from November 2015 until September 2016. This period represents current scenario in the newspaper coverage of Islam, within which related events are happening around the globe. This time frame was chosen to make the data into manageable size for analysis. Considering the large number of articles, a sampling procedure was used to generate a reasonable number of articles for inclusion in the study. Rather than selecting a simple random sample of articles, a purposive sample was used. This procedure helps generate samples more representative and suitable for the study. Purposive sampling is superior to simple random sampling because of its more adequate representation. It enables researchers to select a sample based on the purpose of the study.

\subsection{Data Collection Technique}

The researchers conducted an internet-based search for news articles on Islam. The aim was to locate the news articles relating to Islam in the selected newspapers. The articles were accessed from the respective digital archives of the newspapers. The search method was to type the words "Islam" and "Muslims" as keywords. Any article that focus upon report about Islam or Muslims fulfills the inclusion criteria. The researchers selected articles that touched on issues directly related to Islam. Each article in the original sample was read for relevance. Only straight news and feature news stories were chosen for analysis. 


\subsection{Coding Procedures}

According to Neuendorf (2002), all decisions on variables, their measurement and coding rules must be made before the observations begin. Coding characteristics in the present study included the use of terminology, which consist of expressions of words or compound words. This is because image of Islam can be communicated through the use of language, and that the discourse in news articles should be analyzed in terms of the textual and contextual elements of the texts (Schneider, 2011). Terminology refers to words and compound words or multi-word expressions that in specific contexts are given specific meanings. Terms may deviate from the meanings the same words have in other contexts and in everyday language. At the preliminary stage of coding the data in the present study, all the selected articles, terminological expressions such as Islamist terrorist, Islamist militants, Islamist insurgents were identified using AntConc software, and then each word was searched independently to determine its frequency. AntConc is a corpus analysis toolkit and multi-platform application that include powerful concordancer, word and keyword frequency generators, tools for cluster and lexical bundle analysis (Anthony, 2005). It allows researchers to identify words or group of words that may not necessarily be identified when reading by human beings. Cross-tabulation was used in comparing the news articles, taking into consideration the Islam-related terms used in the selected newspapers. It is a joint frequency distribution of cases based on two or more categorical variables (Michael, 2001).

\section{Findings and Discussion}

The newspapers produced different amounts of articles within the aforementioned period. Nigerian newspapers produced 247 articles while Malaysian newspapers produced 352 articles. The overall of 599 Islam-related articles were analyzed. The aim was to determine the most frequently used Islam-related terms in the newspapers, and examine the context in which the terms were used. To identify the most frequently used Islam-related terms in the articles published by the newspapers, the overall number of the articles $(\mathrm{N}=599)$ were imported into AntConc software in order to generally ascertain the number of terms to be used for the analysis. The terms were identified using "Islam" and "Muslims" as keywords. Subsequently, articles gathered from the selected newspapers of both Nigeria and Malaysia were imported into AntConc separately, and each of the identified terms from the overall articles was used as search keyword to identify its frequency for comparison purpose. The researcher focuses on terms discussed in the previous literature as having used in the media. The following table depicts Islam-related terms identified in the articles of the selected newspapers.

Table 1. Islam-related terms in the selected newspapers

\begin{tabular}{|c|c|c|c|c|}
\hline \multirow[t]{2}{*}{$\mathrm{SN}$} & \multirow[t]{2}{*}{ Term } & \multicolumn{2}{|l|}{ Frequency } & \multirow[t]{2}{*}{ Total } \\
\hline & & Nigerian newspapers & Malaysian newspapers & \\
\hline 1 & Islamist militant & 7 & 53 & 60 \\
\hline 2 & Radical Islam & 3 & 15 & 18 \\
\hline 3 & Islamist attack & 2 & 16 & 18 \\
\hline 4 & Suspected Islamist & 3 & 14 & 17 \\
\hline 5 & Islamist gunmen & 3 & 8 & 11 \\
\hline 6 & Islamic terrorism & 6 & 4 & 10 \\
\hline 7 & Muslim rebel & 0 & 9 & 9 \\
\hline 8 & Radical Islamists & 2 & 6 & 8 \\
\hline 9 & Islamist extremists & 3 & 4 & 7 \\
\hline 10 & Rival Muslims & 7 & 0 & 7 \\
\hline 11 & Moderate Islam & 1 & 6 & 7 \\
\hline 12 & Militant Islam & 0 & 6 & 6 \\
\hline 13 & Islamist fighters & 1 & 5 & 6 \\
\hline 14 & Islamic violence & 2 & 3 & 5 \\
\hline 15 & Islamist militancy & 0 & 5 & 5 \\
\hline 16 & Islamist terror & 1 & 3 & 4 \\
\hline 17 & Islamist threat & 2 & 2 & 4 \\
\hline 18 & Militant Islamists & 0 & 4 & 4 \\
\hline 19 & Islamist killing & 0 & 4 & 4 \\
\hline 20 & Islamist terrorists & 1 & 2 & 3 \\
\hline 21 & Islamic extremism & 2 & 1 & 3 \\
\hline 22 & Islamist insurgent & 2 & 1 & 3 \\
\hline 23 & Islamist violence & 0 & 3 & 3 \\
\hline 24 & Violent Islam & 0 & 3 & 3 \\
\hline
\end{tabular}




\begin{tabular}{|c|c|c|c|c|}
\hline 25 & Islamic jihadists & 2 & 1 & 3 \\
\hline 26 & Islamist terrorism & 0 & 2 & 2 \\
\hline 27 & Muslim extremists & 1 & 1 & 2 \\
\hline 28 & Radicalized Muslims & 0 & 2 & 2 \\
\hline 29 & Deviant Muslims & 0 & 2 & 2 \\
\hline 30 & Islamic threat & 1 & 1 & 2 \\
\hline 31 & Northern Islam & 1 & 0 & 1 \\
\hline 32 & Islamic militancy & 0 & 1 & 1 \\
\hline 33 & Islamic rebel & 1 & 0 & 1 \\
\hline 34 & Islamist jihadist & 1 & 0 & 1 \\
\hline 35 & Islamist propaganda & 1 & 0 & 1 \\
\hline 36 & Islamization agenda & 1 & 0 & 1 \\
\hline 37 & Islamist extremism & 1 & 0 & 1 \\
\hline 38 & Islamist rivals & 0 & 1 & 1 \\
\hline 39 & Islamist conflict & 0 & 1 & 1 \\
\hline 40 & Suspected Islamism & 0 & 1 & 1 \\
\hline 41 & Dangerous Islamists & 0 & 1 & 1 \\
\hline 42 & Islam rebel & 0 & 1 & 1 \\
\hline 43 & Islamist bombings & 0 & 1 & 1 \\
\hline 44 & Islamic shootings & 0 & 1 & 1 \\
\hline 45 & Moderate Islamists & 0 & 1 & 1 \\
\hline 46 & Islamic fundamentalist & 0 & 1 & 1 \\
\hline 47 & Muslim criminals & 0 & 1 & 1 \\
\hline 48 & Muslim crisis & 0 & 1 & 1 \\
\hline 49 & Moderate Muslims & 0 & 1 & 1 \\
\hline 50 & Muslim jihadists & 1 & 0 & 1 \\
\hline 51 & Muslim militants & 0 & 1 & 1 \\
\hline \multirow[t]{2}{*}{52} & Muslim terrorists & 1 & 0 & 1 \\
\hline & Total & 60 & 200 & 260 \\
\hline
\end{tabular}

Table 1 indicates that 260 different Islam-related terms appeared in the selected newspapers. But Malaysian newspapers used more (200) of these terms than Nigerian newspapers, which used only 60 . However, the most frequently used Islam-related term in the selected newspapers is "Islamist militants" which appeared 60 times, followed by "radical Islam" and "Islamist attacks", which came second and third respectively. The most frequently used term, Islamist militants, appeared 53 times in Malaysian newspapers against 7 times in Nigerian newspapers. Again, the terms "radical Islam" and "Islamist attack" appeared 15 and 16 times in Malaysian newspapers against 3 and 2 times in Nigerian newspapers respectively. This indicates that Malaysian newspapers have the highest frequency of the most frequently used Islam-related term compared to Nigerian newspapers.

Of the rest, 9 Islam-related terms appeared only in Nigerian newspapers. In contrast, 24 appeared only in Malaysian newspapers. This clearly shows that Malaysian newspapers used more varieties of Islam-related terms than Nigerian newspapers. Islam advocates peace, tolerance and non-violence, but when the media attach an adjective to it like "militant" or "radical" as having the highest frequency in the selected newspapers, it might be difficult for many non-Muslims to distinguish between the noun and the adjective. Kukah (2011) asserted that "identities began to be narrowed and religion became the basis of identity". This view suggests that religion is becoming the basis of identity, instead of nationality, which will perhaps perpetuate fear particularly of Islam in this regard. By doing so, the media create a particular way for people to think about Islam, as claimed by Agenda Setting theory.

The newspapers described terrorists using several Islam-related words instead of mentioning the groups' names, for example IS, Al-Shabab, Al-Qaida. They focus mainly on terms such as "Muslim terrorists", "Islamist militants" and "Islamist fighters". Thompson (2013) asserted that using terms such as "Muslim Terrorist" without mentioning the terrorist group's name might imply negative depiction of Islam. The following figure shows the context in which the most frequently used term appeared in all the selected newspapers. 


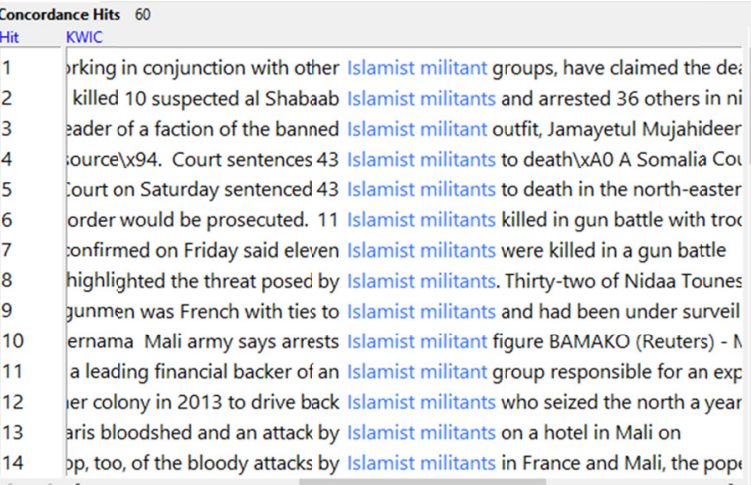

Figure 1. Most frequently used Islam-related term

Figure 1 demonstrates that "Islamist militant" appeared 60 times in the overall articles published by Nigerian and Malaysian newspapers. It can be observed from the figure that the term is used mostly in negative context. In this regard, some studies (Allen, 2001; Haque, 2012) demonstrated that inappropriate use of terms such as extremist, fundamentalist, fanatic and terrorist to describe Islam is prevalent in newspaper reports. It was found that the newspapers have changed the meaning of several words through using them to construct Muslims, for example, the words jihad and Islam. Similarly, Moore et al. (2008) found that the most common nouns used in relation to Muslims were terrorist, extremist, Islamist, suicide bomber and militant while the most common adjectives used were radical, fanatical, fundamentalists, extremists, and militant. Schneider (2011) argued that the typical Muslim's belief in a "moderate Islam" assigns the "usual Islam" the quality of being non-moderate. It is therefore argued that news is usually framed using terminology.

It should be noted that newspapers use a variety of Islam-related terms in different ways, depending on their choice of words or intention of usage. For instance, Thompson (2013) found that the most common nouns in Britain print media are "terrorist" with 22 percent of the total amount and "extremist" with 18 percent of the total amount, and that these nouns have negative connotations. Thompson found 287 varying examples of adjectives in conjunction with Islam or Muslims, such as "militant Muslim" or "extremist Islam". There were few instances of more positive adjectives, and the most common adjectives were "radical" and "fanatic" with negative connotations. As can be seen from Table 1, the newspapers favor different terms, and in some cases use the same terms coincidentally. For instance, the terms "Islamist militant", "radical Islam" and "Islamist attack" are mostly used more in Malaysian newspapers than in Nigerian newspapers.

\subsection{Alternatives to Islam-Related Terms}

The findings reported in this study comparatively examined the use of terminology in selected Nigerian and Malaysian newspapers. It was evident that the newspapers used a variety of Islam-related terms to report Islam, and most of these terms were used in negative context. Instead of mentioning the insurgent groups with their names, for example IS, Al-Shabab, Al-Qaida without ascribing them to Islam, the newspapers focus mainly on terms such as "Muslim terrorists", "Islamist militants and Islamist fighters". It was found that the most frequently used Islam-related terms in the selected newspapers are "Islamist militants", "radical Islam", and "Islamist attacks". The following table presents some suggested alternatives to the terms used in reporting Islam.

Table 2. Alternative terms

\begin{tabular}{ll}
\hline Term & Alternative \\
\hline Islamic Terrorism & Terrorism, terrorist \\
Jihad, Jihadist & Violence, Terrorism \\
Islamist, Islamism & Name of the group whenever possible \\
\hline
\end{tabular}

As depicted in Table 2, "terrorism" should be an alternative to "Islamic terrorism". This is because the term "Islamic terrorism" suggests that terrorism can be Islamic in nature, meaning, the Islamic beliefs can be consistent with that of terrorism. Also the word "jihad" should not be synonymous with violentce because in Islam, it refers to struggle to move closer to God or to adopt Islam's complete way of life. It is a primarily 
non-violent, positive and individual act by a devoted Muslim (Wariboko (2015). Thus, "violence" or "terrorism" should be an alternative to "jihad". Meanwhile, "Islamist" or "Islamism" should be replaced with group's name whenever possible, for example "al Shabab Islamist militants" should be "al Shabab militants" as in the case of second instance from Figure 1. The word "Islamist" is frequently used by the media to describe Islamic extremist or terrorist acting in the name of Islam (Search for Common Ground, 2016). If journalists find it necessary to use such terms, they must make an effort to understand their proper definitions and use them appropriately. Journalists should also explain that words such as "fundamentalist" and "extremist" are not unique to Islam (Allen, 2014). Newspapers should mind the use of terms in reporting Islam to avoid negative perception about the religion (Ameli et al., 2007).

\section{References}

Abbas, T. (2001). Media capital and the representation of South Asian Muslims in the British Press: An ideological analysis. Journal of Muslim Minority Affairs, 21(2), 245-257. http://dx.doi.org/10.1080/1360200120092833

Ahmad, F. (2006). British Muslim perceptions and opinions on news coverage of September 11. Journal of Ethnic and Migration Studies, 32(6), 961-982. http://dx.doi.org/10.1080/13691830600761479

Akbarzadeh, S., \& Smith, B. (2005). The representation of Islam and Muslims in the media. School of Political and Social Inquiry. Retrieved from http://trove.nla.gov.au/version/9562862

Ali, M., Mohideen, H., \& Mohideen, S. (2008). The language of Islamophobia in Internet articles. Intellectual Discourse, 16(1), 73-87.

Ali, S., Khalid, M., \& Lodhi, M. I. (2009). Negative image of Islam and US mass media: How to improve the image of Islam and Muslim countries. Social Sciences andHumanities, 25(2), 43-49.

Allen, C. (2001). Islamophobia in the media since September 11th. Paper presented at the conference of the Forum against Islamophobia and Racism, London. September 2001. Retrieved from $\mathrm{http}: / / \mathrm{www}$.fairuk.org/docs/islamophobia-in-the-media-since-911-christopher

Allen, F. (2014). Islamophobia in the UK: the role of British newspapers in shaping attitudes towards Islam and Muslims (Doctoral dissertation). University of Wales, UK. Retrieved from http://repository.uwtsd.ac.uk/id/eprint/413

Ameli, S. R., Marandi, S. M., Ahmed, S., Kara, S., \& Merali, A. (2007). The British Media and Muslim Representation: The Ideology of Demonization (1st ed.). England: Islamic Human Rights Commission

Anthony, L. (Ed.). (2005). AntConc: design and development of a freeware corpus analysis toolkit for the technical writing classroom. Proceedings from IPCC '05: International Professional Communication Conference. Madison, WI, USA. Retrieved https://pdfs.semanticscholar.org/8fcf/61b24235fd4866993ac2cee72e92f100a9b1.pdf

Baker, P., Gabrielatos, C., \& McEnery, T. (2013). Representations of Islam in the British Press 1998-2009. The ESRC Center for Corpus Approaches to Social Science, Lancaster University, UK. Retrieved from http://www.researchcatalogue.esrc.ac.uk/grants/RES-000-22-3536/read

Cissel, M. (2012). Media framing: A comparative content analysis on mainstream and alternative news coverage of Occupy Wall Street. The Elon Journal of Undergraduate Research in Communications, 3(1), 67-77.

Dart, J., \& Allen, J. R. (2000). Bridging the Gap: Religion and the News Media. Washington, DC: Forum First Amendment Center.

Folarin, B. (1998). Theories of Mass Communication: An Introductory Text. Ibadan: Stirling Horder Publishers (Nig.) Ltd.

Fourie, P. J. (2001). Media Studies: Institutions, Theories, and Issues. Claremont: Jutaand Company Ltd.

Gardner, R., Karakaşoğlus, Y., \& Luchtenberg, S. (2008). Islamophobia in the media: A response from $\begin{array}{lllll}\text { multicultural education. } & \text { Intercultural }\end{array}$ https://doi.org/10.1080/14675980801889658

Haque, F. (2012). Global Media, Islamophobia and its Impact on Conflict Resolution. Retrieved from http://www.ihmsaw.org/resourcefiles/1260034024.pdf

Jacobsen, S. J., Jensen, T. G., Vitus, K., \& Weibel, K. (2012). Analysis of Danish media setting and framing of Muslims, Islam and racism. from 
http://www.ces.uc.pt/projectos/tolerace/media/Working\%20paper\%205/Analysis\%20of\%20Danish\%20Me dia\%20stting\%20and\%20framing\%20of\%20Muslims\%20Islam\%20and\%20racism.pdf

Kukah, M. H. (2011). Religion, Politics and Power in Northern Nigeria. Ibadan: Spectrum Books Ltd.

Langer, R. (1997). The concept of discourse in the analysis of complex communication events. Retrieved from http://openarchive.cbs.dk/bitstream/handle/10398/7028/wpnr.2\%201997.pdf?sequence=1

McCombs, M., \& Shaw, D. (1972). The Agenda-Setting function of mass media. Public Opinion Quarterly, 36(2), 176-187. https://doi.org/10.1086/267990

McQuail, D. (1987). Mass Communication Theory: An Introduction (1st ed.). Beverly Hills, CA: Sage Publications Inc.

Michael, R. S. (2001). Crosstabulation \& Chi square. Indiana University, Bloomington. Retrieved from http://www.indiana.edu/ educy520/sec5982/week_12/chi_sq

Moore, K., Mason, P., \& Lewis, J. M. W. (2008). Images of Islam in the UK: The representation of British Muslims in the national print news media 2000-2008. Retrieved from http://orca.cf.ac.uk/id/eprint/18277

Nanabawa, S. (2013). A Discourse Analysis of Print Media Constructions of "Muslim" People in British Newspapers (Master's Thesis). Rhodes University, South Africa. Retrieved from http://hdl.handle.net/10962/d1006767

Nayan, S. M. (2017). Covering up and speaking up! A rhetorical analysis of hijabi narratives. Journal of Nusantara Studies, 2(1), 40-52.

Neuendorf, K. A. (2002). The content Analysis Guidebook. London: Sage Publications.

Okwuchukwu, O. G. (2014). The Influence of Media Ownership and Control on Media Agenda Setting in Nigeria. International Journal of Humanities Social Sciences and Education, 7(1), 36-45.

Palys, T. (2008). Purposive sampling. In L. M. Given (Ed.), The Sage Encyclopedia of Qualitative Research Methods, 2, 697-698. Los Angeles: SAGE Publications.

Potter, J. W. (2012). Media Effects. California: SAGE Publication Limited.

Rane, H., Ewart, J., \& Martinkus, J. (2014). Media-Generated Muslims and Islamophobia. In Media Framing of the Muslim World (pp. 29-46). Basingstoke: Palgrave Macmillan. https://doi.org/10.1057/9781137334831_3

Ridgeon, L. (2013). Islamic Interpretations of Christianity. Milton Park: Routledge.

Ridouani, D. (2011). The representation of Arabs and Muslims in western media. Ruta: revista universitària de treballs acadèmics, 2(3), 45-57.

Said, E. (2000). Arabs, Islam and the Dogmas of the West. Orientalism: A Reader, 104. Retrieved from http://www.nytimes.com/1976/10/31/archives/arabs-islam-and-the-dogmas-of-the-west-arabs.html

Saidu, S. (2014). A comparative analysis of production sharing contracts of selected developing countries: Nigeria, Indonesia, Malaysia and Equatorial Guinea. Journal of Finance and Accounting, 2(2), 34-40.

Schneider, E. T. (2011). The Reproduction of Islamophobia in German and Dutch Newspaper Discourse: An Analysis from a Critical Discourse Analytical Perspective (Bachelor's thesis). University of Twente, Netherlands. Retrieved from http://purl.utwente.nl/essays/61108

Search for Common Ground. (2016). Terminology Guide. Partners in Humanity team: for constructive and vibrant Muslim-Western relations. Whashington, DC. Retrieved from http://www.commongroundnews.org/lib/Muslim-Western_Terminology.pdf

Shadid, W., \& Van Koningsveld, P. S. (2002). The negative image of Islam and Muslims in the west: Causes and solutions. Religious Freedom and the Neutrality of the State: the Position of Islam in the European Union. Leuven: Peeters, 1(3), 174-196.

Soroka, S. N. (2002). Agenda-Setting Dynamics in Canada. Vancouver, British Columbia: UBC Press.

Thompson, P. M. (2013). Allen's Islamophobia and the British news media: A critical Evaluation of Islamophobia as a Concept and its Application to the Written News Media in Britain between 2001 and 2008 (Master's Thesis). University of Wales, UK. Retrieved from http://repository.uwtsd.ac.uk/id/eprint/354

Thussu, D. K. (2011). How media terrorism manipulates Truth. Economic and Political Weekly, 32(6), 264-267. 
Wariboko, O. P. (2015). Prospects of Islamophobia in Nigeria and its dangers. Journal of Religion and Human Relations, 7(1), 42-52.

\section{Copyrights}

Copyright for this article is retained by the author(s), with first publication rights granted to the journal.

This is an open-access article distributed under the terms and conditions of the Creative Commons Attribution license (http://creativecommons.org/licenses/by/4.0/). 